\title{
IN GESPREK MET AMERIKAANSE ORGANISATIEDESKUNDIGEN
}

\author{
door H. Reinoud
}

Een verblijf in de Verenigde Staten in het voorjaar van 1957, verband houdende met de studie van automatiseringsvraagstukken, gaf mij gelegenheid van gedachten te wisselen met enige organisatiedeskundigen en leidende functionarissen van het Stanford Research Institute, dat zich o.a. ook met bedrijfseconomisch onderzoek bezig houdt. In verband daarmede volgen hieronder enige indrukken en beschouwingen.

$\S 1$. Een bezoek aan het Stanford Research Institute (S.R.I.), Menlo Park, California, gold in de eerste plaats het zgn. ERMA-project (Electronic Recording Machine, Accounting) en de daar ontwikkelde techniek van het lezen van met magnetische inkt gedrukte cijfers, de zgn. character recognition, welke een diepgaande invloed heeft uitgeoefend op de aanbevelingen van de American Bankers' Association ten aanzien van de te volgen methodiek bij het sorteren van cheques. ${ }^{1}$ )

Omtrent het Instituut vernam ik de volgende bijzonderheden. Hoewel er een verband bestaat tussen de Stanford University en het Stanford Research Institute - hun gebouwen bevinden zich in elkaars onmiddellijke nabijheid en zij hebben dezelfde president -, is toch het Research Institute organisatorisch en financieel een zelfstandige instelling. Het is in 1950 opgericht en telde tijdens mijn bezoek niet minder dan 1400 onderzoekers en employê's, de meesten werkend op full time basis. Alle onderzoeken moeten financieel self-supporting zijn, d.w.z. de onderzoekers van het Instituut moeten een bedrijf, overheidslichaam of andere instelling - bijv. de een of andere "Foundation" - bereid vinden hun onderzoek te financieren. Zo is het ERMA-project annex het onderzoek naar sorteer- en selecteermethodieken van cheques gefinancierd door de Bank of America - naar men zegt met 4 à 5 miljoen dollar -, die daarmede tevens in het aanvankelijk bezit van de patenten is gekomen.

Het Instituut beweegt zich op een zeer uitgebreid terrein. Algemeen economisch en bedrijfseconomisch onderzoek maakt er een belangrijk onderdeel van uit. In de laatste jaren is marktonderzoek een researchactiviteit van belang geworden. Er is ook een afdeling ,OfficeAutomation Research", waarvan de leider elk jaar in de gelegenheid wordt gesteld een wereldreis te ondernemen om zich in het bijzonder op de hoogte te stellen van de ontwikkelingen op het gebied van de elektronische reken- en administratietechniek. 2)

Binnen het Instituut is een „International Industrial Development Center" opgericht, waarvan de doelstelling uit de volgende omschrijving blijkt.

„Through applied economic and technical research, the new Center will contribute to economic and industrial development in various countries of the world. It will study and pinpoint specific developmental possibilities with emphasis on the scientific analysis of factors affecting private investment."

Als overal in de U.S.A. was er intense belangstelling voor de Euromarkt. Mede in verband daarmede had het Instituut sinds kort een filiaal

1) Voor enige mededelingen over de studie van automatiseringsvraagstukken verwijs ik naar Economisch-Statistische Berichten van 11 sept., 16 okt. 1957 en 22 en 29 jan. 1958.

2) Hij vertelde mij o.a. dat alleen Japan het land is waar het aanbod van ingenieurs en „,scientists" de vraag ver overtreftl 
voor "techno-economic services" in Zürich gevestigd. 3) Er zijn van ouds in de Verenigde Staten universiteiten met geaffilieerde onderzoekinstituren, maar wat mij bij het S.R.I. trof, was de onwaarschijnlijke expansie, het brede terrein waarop het zich beweegt en vooral het feit, dat het een dependance in Europa heeft opgericht. Wat dit laatste aangaat deed ik sindsdien de ervaring op, dat er bij tal van bedrijven en instituten concrete belangstelling is voor de vestiging van wetenschappelijke filialen in ons werelddeel. Zwitserland, Frankrijk en Nederland komen daarbij veelal als vestigingsplaats in beschouwing. Bijna altijd valt ons land af en richt zich de keuze tenslotte op $Z$ witserland.

Ik vroeg nog of een dergelijk instituut met zijn vele interessante onderzoeken en de daarvan uitgaande zuigkracht op wetenschapsbeoefenaren niet het gevaar inhield, dat de aandacht van deze laatsten te uitsluitend in de richting van het specifieke praktische onderzoek wordt geleid. Een gevaar dat mij des te groter leek door de losse band tussen universiteit en onderzoekinstituut. lk kreeg op mijn vraag geen duidelijk antwoord.

$\S 2$. Mijn volgend bezoek betrof de organisatieafdeling van de Standard Oil Company of California (SOCOC) en zijn leider, de heer L. L. Purkey. De heer Purkey en zijn bekwame medewerkers - thans de heren Piersol en Voorhies - hebben veel pionierswerk op organisatiegebied verricht. Desgevraagd deelde de heer Purkey mij over zijn ontwikkeling tot organisatieexpert het volgende mede.

Tijdens de crisis van de dertiger jaren werd hij belast met een studie van het transportbedrijf van zijn maatschappij en slaagde er toen in het aantal transportwagens van 5000 tot op ongeveer 3000 te reduceren. In feite was dit een soort bezuinigingswerk op grote schaal - op de pay roll zoals hij het noemde -, maar het opende hem de ogen voor de grote waarde van een systematische doordenking en aanpak van het organisatiewerk door middel van een daarop verbijzonderd orgaan. Hij wist de toenmalige bedrijfs leiding van de SOCOC voor zijn ideeën te winnen en zo vervult hij reeds sinds 1931 de functie van ,manager of the organization department".

In het gebied van het organisatiestruktuurwerk behoort de heer Purkey ongetwijfeld tot de voortrekkers. $\mathrm{Hij}$ is een van de eersten, misschien wel de eerste geweest, die zich bezig heeft gehouden met de systematische beschrijving van de voornaamste functies in een bedrijf op basis van zorgvuldig onderzoek en een logisch doordacht plan gevolgd door de samenvatting ervan in een handleiding (en).

In 1948 publiceerde de SOCOC een prototype van een dergelijke handleiding, .,The Management Guide", een voortreffelijke studie waarvan men de instructieve waarde niet hoog genoeg kan aanslaan. Dit prachtige werkstuk heeft in hoge mate stimulerend gewerkt op het samenstellen van struktuurgidsen - soms wat verschillend van opzet - door andere ondernemingen in en buiten de Verenigde Staten.

Naar aanleiding van mijn vraag welke ervaringen met ,The Management Guide" waren opgedaan deelde de heer Purkey mij mede, dat sinds de verschijning in 1948 niet minder dan 22000 exemplaren waren verstrekt aan bedrijven en universiteiten in de Verenigde Staten en 26 andere landen. Sinds kort was een tweede iets gewijzigde druk verschenen. De belangstelling voor deze arbeid is zo groot, dat hij alleen voor "internationale" inlichtingen over de management guide een aparte secretaresse heeft moeten aanstellen. ,The Management Guide" is voorts vertaald in het Duits, Italiaans en Japans.

3) Bezetting: 2 chemici en 2 economen.

m a b blz. 376 
De tweede in 1956 verschenen druk is volgens de heer Purkey niet wezenlijk veranderd en ook het voorbericht suggereert dat. De buitenstaander vallen echter toch enige bijzonderheden op. Allereerst is de inleiding tot het onderdeel ,Responsibilities and authority" van iedere functie verkort tot een verwijzing naar "established policies". Een interessante wijziging, die illustratief is voor de voortgaande ontwikkeling van de bedrijfsleer. Wanneer men de ontwikkeling van de organisatieleer vanaf Taylor tot aan de laatste wereldoorlog zou willen typeren, dan zou men dat o.a. kunnen doen door te wijzen op de ontwikkeling van de ,aanpak" van onderaf naar boven, n.l. van de bestudering van technieken, die zich richten op beheersing van de actie op de onderste geleding van de uitvoering (methoden en procedures) naar vraagstukken als budgetorganisatie en struktuur van het gehele bedrijf. 4) De ontwikkeling na de oorlog doet, bij wijze van spreken, een stap verder omhoog door zich rekenschap te geven van het feit, dat alle maatregelen in een bedrijf, dus ook en vooral die met betrekking tot organisatievraagstukken, voorafgegaan moeten worden door een bezinning op en formulering van het beleid (policy formulation), zowel in grote lijnen voor het bedrijf in zijn geheel als daarvan afqeleid voor zijn onderdelen. Reeds bij een vorig bezoek bleek mij, dat de SOCOC bij de opbouw van zijn management guide - eigenlijk vanzelfsprekend - op dit probleem was restuit en al ceruime tijd aan systematische ..policy formulation" deed (Policy manuals worden uiteraard nooit gepubliceerd omdat zij het essentiële van het bedrijfsbeleid bevatten). De opmerking in de nieuwe druk hii vriiwel elke functie. . The responsibilities and authority stated below are subject to established policies", moet mede in het licht van deze ontwikkeling worden gezien.

De functie van de comptroller (aldus bij de SOCOC gespeld) is thans iets anders omschreven dan vroeger. $\mathrm{Nu}$ is vermeld, dat hij ten aanzien van policies riet alleen medewerkt. maar ook zorat voor de ,.establishina" daarvan. In de eerste druk kwam in de functieaanduiding van de comptroller ook ..auditina" voor, maar verder werd daaromtrent niets vernomen. In de nieuwe definitie is onder ., activities" nadrukkelijk vermeld ,conducts the internal auditing program".

In het M.A.B. van iuli 1956 heeft H. C. Treffers aepleit voor plaatsing van de interne accountantsdienst rechtstreeks nnder de president-directeur van een bedriif of onder de collectieve directie. De praktijk in de Amerikaanse bedriiven is veelal een andere en ik mpen dat daar, althans voor de arote bedrijven, motieven voor kunnen worden aangevoerd, die het overwegen zeker waard ziin. Ik kom daarop te zijner tijd in een afzonderlijke beschouwing terug.

Wat de ordanisatie-afdeling aangaat. deze was in de Amerikaanse bedrijven. waar ik, ook bij vorige geleqenheden, van de bedrijfsstruktuur heb kunnen kennisnemen meestal of onder de nresident of onder de comntrnller gesteld met. naar ik meen. een tendenz in de laatste richting. Bii de SOCOC ressorteert de nrqanisatie-afdelinq onder de president. Voor diegenen onder de lezers, die reen tiid kunnen vinden kennis te nemen van ..The Manacement Guide" laat ik hieronder de functieomschrijving van de comptroller en die van de leider van de orqanisatio-afdelina (nieuwe editie) volgen.

4) Ik zie hier vooral op de praktiik: Harrinnton Emerson en Payol bezagen de organisatie reeds de eerste periode van de Scientific Manaqement beweainq van boven af, maar de meeste in de praktilk werkende organisatieadviseurs richtten zich in hoofdzaak op methoden en procedures. Ook nu nor. In het boekje "Organisatie-facetten" van het kantoor Berenschot N.V. behandelt slechts één van de tien artikelen, n.l. dat over bouwteams, een struktuurfacet. 
„Comptroller. Controls and co-ordinates accounting, auditing, budget, tax, and related activities and records; develops, establishes, and administers policies and procedures pertaining to such matters; prepares financial reports, statements, forecasts, and analyses; and conducts such activities for the Manager of the staff departments."

.Manager. Organization Department. Furnishes functional guidance to the heads of the organizational components of the company by advising and assisting in the development, maintenance, and improvement of plans of management embracing; organization structures and complements; functions, responsibilities and authority, and relationships; control over wages, salaries, operating expenses, and manpower; and company, department, and division policies on these matters."

In de eerste management guide was bij de verschillende functieomschrijvingen vermeld, dat de betrokkene zijn taak had in te stellen op die van anderen en dat hij in de daarvoor in aanmerking komende gevallen advies van de in de organisatie opgenomen adviesorganen had in te winnen. Thans komen deze mededelingen niet meer in die vorm voor, maar zijn vervangen door een algemene opmerking in de inleiding.

„Staff assistance and services. Seeks, receives, and utilized the advice, assistance, consultation, and guidance available from other agencies within the company with respect to any action or decision, as appropriate."

Als verklaring voor deze wijziging wordt vermeld, dat door dergelijke opmerkingen in elke functie- en taakomschrijving op te nemen, ,a large part of the value of such Guides through creating an adverse reaction by talking down to the individual" verloren kan gaan. Ik ben het hiermede niet geheel eens. De ervaring in tal van andere bedrijven is, dat het geenszins overbodig is om in elke functiebeschrijving op te nemen, dat de betrokkene van de in het bedrijf aanwezige orqanen of adviseurs gebruik moet maken. Vermoedelijk is dat bij de SOCOC door de langdurige gewenning aan staforganen en de gedisciplineerde geest vanzelfsprekend geworden, maar bij andere bedrijven zal de bedoelde opmerking in de functie- en taakomschrijvingen zeker geen luxe zijn, althans in een lange overgangsperiode (zoals aanvankelijk bij de SOCOC!).

Ook voor de hoogste leidende functionarissen heeft de SOCOC positieomschrijvingen. Vanwege de aard van deze functies (of de functionarissen?) zijn deze echter meer in grote lijnen gehouden en samengevat in „Executive Guide(s)". Dit soort gidsen wordt niet aan derden verstrekt, maar een prototype van enkele van deze functie- en taakbeschrijvingen, n.l. van de ,Director and Vice President Manufacturing and Research" en de .Vice President Finance", is in de nieuwe management guide opgenomen. Bij lezing ervan dient te worden overwogen, dat bij andere bedrijven de functie- en taakinhoud van de betreffende functionarissen een wat andere kan $z$ ijn. Men denke aan het samengaan of gescheiden zijn van de functies van comptroller en treasurer.

Wie zich voor een systematische letterlijke vergelijking van de eerste en de tweede druk van ,.The Management Guide" van de SOCOC interesseert. kan een copie van een door de organisatie- en efficiencyafdeling van de PTT terzake opgesteld overzicht verkrijgen. ${ }^{5}$ )

Het organisatiewerk wordt bii de SOCOC gedecentraliseerd uitgevoerd. De vele onderdelen van de SOCOC hebben n.l., indien de kwantitatieve verhoudingen dat rechtvaardigen, een eigen organisatie-afdeling, die deel uitmaakt van de hierarchie van het betreffende onderdeel, maar onder de ",functional guidance" van de organisatie-afdeling werkt. De employé's van die afdeling krijgen zoveel mogelijk hun opleiding en vorming op de

5) Centrale Directie PTT, Kortenaerkade 12, Den Haag, Kamer B. 20. Het overzicht omvat $11 \mathrm{blzn}$. 
centrale afdeling organisatie; er wordt, zo noemde de heer Purkey het, naar een "fluid state" gestreefd. Als norm voor de volledige en economisch verantwoorde tijdsbezetting van een afzonderlijke organisatieadviseur noemde de heer Purkey een personeelsomvang van 200 arbeiders of employé's.

De leiding van de SOCOC is een groot voorstander van vergaande decentralisatie. Evenals zovelen heeft ook de heer Purkey de ervaring opgedaan, dat een dergelijke decentralisatie op tal van irrationele weerstanden stuit. „People believe by instinct in centralization", merkte hij op. In verband daarmede is bij de SOCOC een vaste commissie voor decentralisatie ingesteld, die alle bestaande en nieuwe activiteiten op hun mogelijkheden tot decentralisatie beoordeelt. Deze commissie, die overwegend uit fulltimers bestaat, heeft als opdracht decentralisatie op verantwoorde wijze te bevorderen indien en waar enigszins mogelijk. In feite is deze decentralisatiecommissie dus als permanent orgaan in de bedrijfsstruktuur van de SOCOC opgenomen. Het lijkt mij toe, dat de heer Purkey c.s. ook hiermede weer een waardevol initiatief hebben genomen. Decentralisatie van bestuur en uitvoering - met gecentraliseerde controle ten behoeve van het corrigerend element in de leiding - wordt door velen terecht als een nastrevenswaardig beginsel erkend, maar er komt in de praktijk meer dan eens weinig van terecht.

De oorzaak daarvan ligt veelal bij de topleiding, die òf zelf moeilijkheden met de doorvoering van een decentralisatiepolitiek heeft, die zij mentaal voorstaat, of wel niet in voldoende mate bij machte is het door haar uitgestippelde decentralisatiebeleid ten uitvoer te leggen. Een vaste commissie voor decentralisatie kan daarom te dien aanzien goede diensten bewijzen, indien haar leden althans voldoende beleidsinzicht en gevoel bezitten en voorts voldoende poids hebben om tegen ongemotiveerde weerstanden ,.aan te drukken". Wanneer zij voor de verzameling en beoordeling van feiten, maatregelen, e.d. gebruik maakt van de bestaande organen van het bedrijf, bijv. de organisatie- en de personeelsafdeling. dan behoeft zij bovendien niet aroot van omvang te zijn.

Wat nu de decentralisatie en het zich aan de top beperken tot de essentiële beleidselementen aancaat, heeft de SOCOC vorig jaar een belangrijke stan gedaan. De SOCOC omvarte zoals zovele grote ondernemingen een aroot aantal qemengde bedriiviaheden. $\mathrm{Z}_{\mathrm{ij}}$ was .,holding company" van dochtermaatschappijen, maar had ook vele eicen onerationele activiteiten. De ervaring leerde. dat hoezeer de centrale leirina ook streefde naar concentratie on het belanqrijkste werk. de top toch chronisch overbelast was geraakt. Tijdens de aroei in de na-oorloase jaren kregen steeds meer. overigens hoge, bedrijfsfunctionarissen rechtstreeks acces tot de president en zijn naaste medewerkers. De laatste iaren waren dat er niet minder dan 28, waardoor deze laatsten door de bomen het bos niet meer konden zien en belangrijke ontwikkelingen in en buiten het bedrijf aan de aandacht dreigden te ontsnanden. Men heeft daarom via een andere struktutur annex rechtsvorm een verdero dam nogeworpen tegen het naar de top stiicen van relatief minder belancriike zaken. In een beschouwina over beleir ( shepaling) en de controle daaron. die ik over enice tiid in dit blad hoop te publiceren. kom ik nader uitvoerig op deze problematiek en tevens op de evenbedoelde reorqanisatie terug.

Een punt dat de laatste jaren bij de SOCOC. evenals bij vele andere Amerikaanse maatschappijen, bijzondere aandacht heeft, is de beloning van het zon. hoger personeel, waarbij aan een vrij ruime groep functionarissen 
- de heer Purkey noemde 8 a $10 \%$ van de salaristrekkenden - moet worden gedacht. De organisatie-afdeling van de SOCOC studeert veel over de hoogte en het systeem van beloning van deze groep (om misverstand te voorkomen: $z \mathrm{ij}$ weet heel goed, dat geld niet alleen de satisfactie in het werk en de produktiviteit bepaalt). Z $\mathrm{ij}$ ontwierp een eigen ,,jobevaluation system" - zonder puntentelling - voor bedoelde groep en streeft er voorts naar het personeel de salarispolitiek, die het bedrijf volgt, zo duidelijk mogelijk te maken. Kortgeleden heeft zij daarover een vrij uitvoerige en lezenswaardige publicatie ( $74 \mathrm{blz}$.) het licht doen zien, getiteld "People and Pay Checks", waarvan thans reeds een herdruk van 10000 exemplaren in voorbereiding is. ${ }^{6}$ )

Een bijzonder probleem van deze tijd is alles wat de zgn. research en ontwikkeling, in het bijzonder ook in de bedrijven, aangaat. $\mathrm{E}_{\mathrm{r}}$ is momenteel te dien aanzien zoveel belangwekkends aan de orde. dat ik het in het kader van deze beschouwing zelfs niet bij benadering kan aanduiden. Slechts een tweetal punten, die in het gesprek met de heer Purkey ter sprake kwamen, vermeld ik hier.

Allereerst (alweer) de salariëring. Bij herhaling bleek de moeilijkheld, dat knappe researchwerkers geen leidinggevende capaciteiten hadden en daardoor de promotieladders, die mede daarop gebaseerd waren, niet tot de top konden bestijaen. In verband hiermede is de SOCOC overgeqaan tot een systeem van gelijke beloning voor de hoge leidinggevende functionarissen in de laboratoria en de succesvolle researchwerkers.

Het tweede punt betrof de budgettering der laboratoria. Bij de PTT heeft $z$ ich bij de studie van de invoering van een budretsysteem de vraag voorgedaan of de budrettering zich ook tot het PTT-laboratorium moest uitstrekken. De heer Purkey vertelde mij nu, dat ook in zijn bedrijf de moeilijkheid naar voren was gekomen, dat speurwerkleiders veel bezwaren ontwikkelden tegen een voorgenomen budretsysteem en de indiening van een daaraan ten arondslad liqgend werknlan. Door de enorme kosten der laboratoria en de sterke opwaartse tendenz daarin hleek bij nadere overweging toch een zekere mate van budaettering en beoordelinq van hoger hand van de werkplannen - mede met het oog op de coördinatie van de verspreide laboratoria - onontkoombaar.

Om evenwel de garantie te aeven. dat er volop oog was voor de bijzondere omstandirheden en het aparte klimaat. waarin researchwerkers, althans een deel van hen. mneten werken, is toen besloten om een in het researchwerk aroot aeworden functionaris, een vooraanstaand chemicus, te belasten met het met raad en daad biistaan van de hudretafdelina bii haar contact met de lahoratoria (als .. friend in court" noemde de heer Purkey dat). Dit heeft uitstekend rewerkt en thans is zijn hulp niet meer nodiq.

De financieel-economische controle van het researchwerk bleek mij later - zoals ik trouwens uit publicaties reeds vermoedde - overal in optima forma een vraacstuk. Bii geen enkel bedriif, waar ik informeerde, ontbrak een vorm van hedriifsbearotina voor de laboratoria. Maar overal werd, evenals bii de SOCOC. nadrukkeliik npgemerkt. dat bij de beoordeling van de werkplannen en bij de verceliikinq van het ,.soll" en het ,.ist" geheel andere maatstaven worden aancelead dan bii de andere bedrijfsonderdelen.

Het verhaal aing vroeger, dat de grondlequer van de I.B.M., wijlen de heer Watson $\mathrm{Sr}$. gaarne vertelde dat zijn gehele bedrijf gebudgetteerd was

b) In het algemeen verstrekt de SOCOC één exemplaar van haar publicaties gratis. Voor meerdere exemplaren moet een vergoeding betaald worden; voor de Management Guide bijv. \$1. 
met uitzondering van het laboratorium en de reisactiviteiten van een grote groep van zijn medewerkers. Maar als ik goed ben ingelicht, vallen de laboratoria, die door de naoorlogse gang van zaken jaarlijks een fantastisch bedrag kosten, nu wel onder een budgetsysteem. 7)

Tot slot van dit gesprek nog iets merkwaardigs. De organisatie-afdeling van de SOCOC heeft op een stuk hard papier van $\pm 21,5 \times 28 \mathrm{~cm}$ (gevouwen) nog een eenvoudige weergave van zijn struktuur met toelichtingen vermeld. Een soort visitekaartje, dat voornamelijk voor interne doeleinden dient. Op dit overzicht viel mij onder het hoofd ..Organization research and training" het volgende op:

"Research and special surveys in organization to develop and disseminate the best thought and practice on organization, manpower utilization, methods, wages and salaries, and the processes of their administration. This research, together with the wide experience gained in normal activities, has led to the preparation of several books by members of the department: Top Management Organization and Control; The Functions of Corporate Secretaries, Treasurers and Comptrollers: The Coordination of Motive, Men, and Money in Industrial Research; The Management Guide; and More Profit - Less Paper. To provide uniform application of established principles or organization, the department provides training and indoctrination for organization personnel, and coordinates such training carried on by other organizational components."

Ik kende al deze geschriften behalve .,Top Management Organization and Control". Op mijn vraag dat dit vermoedelijk wel niet het gelijknamige werk van Holden, Fish and Smith was, kreeg ik ten antwoord: „Dat is het wel. Het is een werk waaraan wij op de SOCOC - o.a. via onze medewerker Fish - zeer veel tijd hebben besteed. Het is voor een belangrijk deel hier gereed gemaakt, de heer Holden heeft ons daarvoor onvoldoende erkenning gegeven. Wij beschouwen „Top Management Organization and Control" mede als een boek van ons en vermelden het daarom als een van onze publicaties (oplage meer dan 15000 stuks)."

Ik hoop met bovenstaande fragmentarische uiteenzetting enig idee te hebben gegeven van het belangrijke werk, dat de organisatie-afdeling van de SOCOC op het gebied van de organisatieleer verricht.

$\mathrm{Na}$ het schrijven van bovenstaande regelen kreeg ik bericht, dat de heer Purkey met ingang van 1 februari j.l. gepensioneerd is en opgevolgd door de heer Piersol.

§ 3 Besprekingen ten kantore van de Bank of America te San Francisco, de grootste bank in de Verenigde Staten, golden in de eerste plaats het zgn. ERMA-project (zie $\$ 1$ ). Toen ik echter naar het bestaan van een organisatie-afdeling informeerde, zat ik kort daarop bij een nog jonge man, de heer C. Terry. De heer Terry bleek chef te zijn van een onderdeel van het Controller's Department, „Organization Planning" geheten, dat zich in hoofdzaak met struktuurvraagstukken bezig houdt. Op een door deze afdeling opgesteld organisatieschema wordt de controller's functie als volgt omschreven.

„Basisfunction: To review and audit all aspects of the general operations of the Bank; develop and interpret information for use by senior management in planning and policy making; develop plans, controls, methods and procedures designed to improve the economy, safety and effectiveness of operations and to measure performance." Als „principal activities" worden opgesomd: 1. Audits and inspections, 2. Cost analysis, 3. Reports and financial analysis, 4. Branch location analysis, 5. Organization planning, 6. Methods and standards, 7. Equipment research, 8. Operations research, 9. Special projects.

7) Voor een critische beschouwing van een laboratoriumleider over bedrijfsbegrotingen voor onderzoeklaboratoria verwijs ik naar het artikel van Prof. Dr H. B. G. Casimir, getiteld "Wetenschap en Techniek" in Philips 'Technisch Tijdschrift van 4 juni 1958. 
Bij de omschrijving van deze taak viel het mij op, dat de boekhouding entbrak. Deze bleek, van ouds, onder de kassier te ressorteren! De organisatie-afdeling was nog van betrekkelijk recente datum. .WWij lopen wat achter de industrie aan", zei de heer Terry, die veel bewondering had voor het organisatiewerk bij de SOCOC en de General Electric. Hij zocht echter, mede door het verschil tussen een industriële onderneming en een bank, zijn eigen weg in de betreffende materie. Aan de hand van verschillende struktuurschema's van eenzelfde bedrijfsonderdeel gedurende een aantal opeenvolgende jaren liet hij mij het groeiproces in de verdieping van zijn analyse zien. Zoals te verwachten was, blijkt de aanpassing van de historische organisatiestruktuur aan de nieuwe ontwerpen moeilijk te zijn. Maar de president van de Bank was, aldus de heer Terry, geleidelijk aan gewonnen voor de grote betekenis van het struktuurwerk en steunde het nu krachtig, zij het bedachtzaam. Een of ficieel organisatieschema was nog niet aanwezig, wel waren er perspectivische schema's.

Voor een eind 1956 gehouden "branch managers leadership conference" was een 26 bladzijden tellend stuk opgesteld, "Notes on Organization", dat de huidige organisatieopbouw van de Bank of America in een aantal overzichtelijke struktuurschema's met eenvoudige toelichtingen weergeeft. Een bladzijde is gewijd aan het oude en altijd weer nieuwe vraagstuk van de verhouding en samenwerking tussen lijn en staf, waarin mij als novum punt 7 opviel: „staff may make decisions for the line but only with the consent of the line". Een regeling, die ondanks haar duidelijke bewoordingen m.i. toch een gevaar voor een goede verhouding tussen lijn en staf kan opleveren. Op de tweede bladzijde van het overzicht staat een schema, waarvan ik de top hieronder vermeld.

\section{Stockholders \\ Board of Directors \\ Executive Committee \\ President}

general trust
committee

(1)
(2) managing committee auditing and examining committee

Onder het schema staat ,,multiple management". In de Verenigde Staten werkt men de laatste jaren veel met de woorden ",multiple management", ..group management" e.d. Het is echter zonder meer nooit duidelijk wat men er precies mee bedoelt en hoe de werking ervan is.

$\mathrm{Bij}$ bovenstaand schema kreeg ik de volgende uitleg. De Board bestaat op de president en de senior vice president na geheel uit buitenstaanders. Ook van het Executive Committee maken uitsluitend buitenstaanders deel uit. De president is lid van de commissies (1), (2) en (3), maar alleen chairman van het managing committee (3). Bij verschil van inzicht - dat weinig zou voorkomen - worden besluiten genomen bij gewone meerderheid van stemmen. De president moet alle genomen besluiten uitvoeren; heeft hij ernstige bezwaren tegen een besluit - ook dit is naar werd medegedeeld zelden het geval -, dan kan hij zich tot het executive committee wenden.

Zoals men ziet spelen commissies hier een belangrijke rol bij besluitvorming, maar is toch een vorm van eenhoofdig leiderschap gehandhaafd. Als subcommissie van het managing committee is nog een junior advisory board vermeld, een soort vormingsgroep voor \pm 30 jongere managers.

m a b blz. 382 
Bij verschillende Amerikaanse bedrijven heeft men in de directie een lid dat als uitsluitende taak heeft het onderhouden en verzorgen van de goede relaties met regeringsinstanties. Zo heeft de Sylvania Electric Products Inc. als „officer" een aparte „,vice president - government relations". Meestal is deze functie ontstaan in verband met regeringsopdrachten en/of met het oog op voortdurende waakzaamheid ten aanzien van voorgenomen overheidsmaatregelen en -acties.

Bij de Bank of America is er op het niveau van de controller een ,governmental relations officer", wiens basic function is:

,"to maintain adequate contacts with all levels of State and Federal Government located in California; follow legislation and litigation which will affect the Bank's activities and present Bank's views $t$ othe proper governmental agencies". 8 )

De heer Terry behoort tot de jongeren; dat verklaart o.a. het feit dat hij in de elementen van het leidinggeven het in de naoorlogse jaren zo op de voorgrond tredende begrip motivation heeft opgenomen. Hij onderscheidt plan, organize, delegate, motivate, control en coordinate (vergelijk Limperg's gestyleerde indeling: constitueren, dirigeren, controleren). Motivate omschrijft hij aldus: „,stimulate subordinates towards the maximum accomplishment of determined objectives".

De heer Terry gaf mij nog ter lezing de rede, door de "assistant to the controller", de heer J. P. Williams Jr, gehouden op de National Conference of the Controllers Institute of America in 1955, getiteld .,The Controller's role in Management Planning and Control" en dat ten doel heeft te bewijzen, dat , a controller is not a controller"!

Een collega-controller, Mr Webster, had als definitie van controller gegeven ,,an officer appointed to check expenditures; a governor, director, dominator or restrainer". "In other words", merkt de heer Williams op, ,apart from the checking of expenditures all other synonyms imply authority. This is our major point of conflict. In fact, the only absolute authority granted to our controller, other than his supervision of his own staff, is the authority to examine or review any activity any time. If, then, our controller

8) In dit verband merk ik op, dat dd 7 februari 1958 een aantal Nederlandse ondernemers
e.a. (t.w. de heren Delprat, van Heek Hz.. Hirschfeld, van der Mandele, van Spaendonck
en Steenberghe) zich tot verschillende Nederlandse bedrijven heeft gewend, waarbij zij
hun bezorgdheid hebben uitgesproken over onvoldoende aandacht bij directies voor de
invloed van resp. de samenwerking met overheidsinstanties ten aanzien van het bedrijfs-
leven. In verband daarmede bevelen zij aan om een speciale functionaris in de directie
uitsluitend voor dit doel vrij te maken. Uit de brief citeer ik het volgende: „Ondergetekenden hebben zich beraden hoe in deze ernstige situatie verbetering kan worden gebracht. $Z_{i j}$ menen, dat dit mogelijk (en noodzakelijk) is, doordat verschillende grote en middengrote bedrijven, naast directeuren, die de technische, commerciële en financiële leiding van de ondernemingen uitoefenen, een directeur (of bij grote bedrijven een adjunct-directeur) voor algemene zaken benoemen. Deze persoon zou zich in de onderneming met algemene aangelegenheden kunnen bemoeien, de directievergaderingen en die van de Raad van Commissarissen bijwonen, doch voor een belangrijk gedeelte van zijn tijd voor algemeen maatschappelijk werk, als boven omschreven, beschikbaar moeten zijn.

Het offer, dat de onderneming hiermede aan het algemeen belang brengt, zal, in de praktijk, waarschijnlijk minder zwaar blijken te zijn dan men op het eerste gezicht zou denken. Immers de betrokken persoon zal in de onderneming door een ervaring op breder terrein in belangrijke mate aan de vorming van de bedrijfspolitiek kunnen meewerken. Het is dan ook niet overdreven reeds nu te waarschuwen, dat men dergelijke personen op den duur niet geheel voor de onderneming in beslag mag nemen. Het bovengestelde doel zou dan niet bereikt worden.

Bovenstaande gedachte is geenszins nieuw. In een rede op de Algemene Ledenvergadering van het Verbond van Nederlandse Werkgevers op 12 oktober 1928 te Groningen heeft de toenmalige voorzitter van dat Verbond, wijlen de heer mr. Aug. Philips, reeds een pleidooi in deze richting, helaas zonder veel succes, gehouden." 
is not a controller, what is he?" En als antwoord op deze vraag noemt de heer Williams vier deelfuncties, n.1. 1. The auditor, 2. The evaluator, 3. The planner, 4. The experimenter.

De functie van auditor behoeft weinig toelichting. Die van evaluator betreft het verkrijgen van de ,measurement tools to evaluate management functions" (anders: "Yardsticks for evaluating managerial performance). Hij tekent daarbij aan: ,This we believe to be our greatest challenge because it represents a function about which little is known and on which decisions will in most part be made by opinion judgment." Die laatste wil hij vervangen door of complementeren met „sounder judgment", gebaseerd op studie en research.

Ik teken hierbij aan, dat er m.i. in verschillende bedrijfseconomische en administratieve beoordelingstechnieken toch wel zoveel voor het beoogde doel beschikbaar is, dat het verkeerd is de indruk te vestigen, dat men op dit gebied geheel met lege handen zou staan, al is er ongetwijfeld nog heel wat te overdenken en te doen.

De functie van planner wordt als volgt toegelicht.

„Such functions as Methods and Procedures Study, Equipment Research, Financial and Tax Research and Organization Planning comprise the overall planning function." Ook de ontwikkeling van de elektronische administratietechniek behoort tot deze deelfunctie. .,The advent of the era of computers and data processing machines certainly represent a major segment of the controller's planning function."

Zoals men ziet een veel omvattend begrip planning

De functie van experimenter wordt als volgt aangeduid.

„Planning, by itself, would only be helpful in some phases of operations. In many others it is necessary in our Organization for the Controller to be an experimenter, as well."

En dan wordt het experimenteren met de IBM 702 en vooral het lezen van cijfers en het ERMA-project vermeld.

"The recent development of an adding machine punch and an Arabic scanner are further examples of the role of experimenter. Most dramatic however was the succesful completion of our electronic bookkeeping machine known affectionately to us as Miss Erma. This was a project in which the Controller had constant and intimate contact with all details of the experiment. In fact Howard Leif, the Controller, who is somewhere in the audience has been spending $100 \%$ of his time in these final stages prior to the sale of plans and patents which we so proudly own."

En tot besluit van de beschouwing volgt dan: ,This is the case history of the Controllers function at Bank of America. Auditor - Evaluator - Planner - Experimenter. The lack of authority does not impede our progress or effectiveness."

I $k$ ben op dit geschrift wat uitvoeriger ingegaan, omdat het nog eens aantoont hoe in de Verenigde Staten, ook onder de controllers zelf, controversiële opvattingen over de controller's functie bestaat. Het zou wel gewenst zijn, dat in ons land het voortreffelijke inleidende artikel van Prof. v. d. Schroeff over de controller's functie ${ }^{9}$ ) - over welks inhoud overigens op enkele punten verschil van inzicht kan bestaan - door een uitvoerige en op nog meer feitenmateriaal steunende studie werd gevolgd.

$\S 4$ In New York ontmoette ik Prof. E. Dale, associate professor in business administration aan de Cornell University en o.a. bekend om zijn boek „Planning and Developing the Company Organization Structure", dat inmiddels in verschillende talen is verschenen.

Bij één der grootbedrijven in de Verenigde Staten, waaraan ik een bezoek

9) M.A.B. dd mei 1953, Een pleidooi voor de invoering van de controller's functie. Brochure-uitgave Muusses Purmerend 1953. 
bracht om een Univac in werking te zien, bleek hij voor de directie als adviseur op te treden in een eigenaardig conflict. Bij gelegenheid van de invoering van deze apparatuur hadden de vakverenigingen - het bedrijf is sterk „unionized" - een groot aantal ",management functions", in dit geval te omschijven als hoger gequalificeerde en betaalde functies, voor hun leden opgeëist, aanmerkelijk meer dan het totale aantal employé's dat de gehele desbetreffende afdeling telde!

Dale legt zich bewust beperking op in de omvang van zijn kantoor, o.a. omdat hij na rijp beraad besloten heeft $z$ ich naast zijn praktijk als organisatie-adviseur ook zoveel mogelijk aan wetenschappelijke arbeid te blijven wijden. $\mathrm{H}_{\mathrm{ij}}$ is $\mathrm{n} . \mathrm{l}$. op het spoor gekomen van belangrijke - onbekende of slechts ten dele bekende - arbeid door leiders van bedrijven, al zeer geruime tijd geleden op het gebied van de zgn. wetenschappelijke bedrijfsleiding gepresteerd, en heeft zich nu tot taak gesteld daarover geleidelijk aan publicaties te doen verschijnen. De eerste twee studies zijn verschenen in het blad ,Administrative Science Quarterly" en heten resp. „Contributions to Administration by Alfred P. Sloan, Jr., and GM (General Motors)" en ,.Du Pont: Pioneer in Systematic Management".

Over enige jaren hoopt hij deze studies in een boek te bundelen. Het onderzoekwerk vraagt veel tijd - onderzoek in archieven, gesprekken met de betrokkenen indien nog in leven en hun vroegere medewerkers, enz. - maar wordt zoals zoveel research in de Verenigde Staten financieel gesteund door een instelling, in dit geval door de Social Science Research Center.

Uit wat Dale en ook anderen mij mededeelden kreeg ik de indruk, dat de Amerikaanse organisatieadviseurs - die zich veelal, te recht of ten onrechte, management consultant noemen - in toenemende mate betrokken worden in de vorming van hoger kader in de bedrijven, de zgn. management development. Deze management development vindt in de Verenigde Staten plaats in en via speciale instellingen, zoals het American Management Association (AMA), verschillende universiteiten (bijv. de bekende Harvard Advanced Management Courses), e.d. Ter voorbereiding daarvan of als nazorg in de bedrijven verrichten nu management consultants met cursussen en voordrachten hun diensten.

In dit verband merk ik op, dat mij gebleken is, dat er nog wel eens het misverstand bestaat, dat bij management development alleen gedacht wordt aan de evenbedoelde vormingscentra (bij ons aan de Stichting Studiecentrum Bedrijfsbeleid).

Hoe nuttig, ja onontbeerlijk dergelijke instituten voor het bedrijfsleven zijn, zij moeten, als het goed is, deel uitmaken van een geheel plan en systeem van hoger kadervorming in de bedrijven, o.a. door systematische carrièrevolging, weloverwogen functiewisseling (jobrotation), eventueel oefening in junior boards, enz. Ik verwijs hierbij naar de lezenswaardige publicatie van het C.O.P. .W Wie volgt ons op?".

$\S 5$ Over de opvallende figuur van Chr. Argyris schreef ik uitvoerig in het M.A.B. van dec. 1955 en jan. 1956 naar aanleiding van diens belangwekkend boek „Executive Leadership". Ik had Argyris indertijd in ons land gesproken en hem de afzonderlijk verschenen vermeerderde herdruk van mijn beschouwingen toegezonden. ${ }^{10}$ ) In deze herdruk heb ik als be$z$ waar tegen Argyris en andere human relations deskundigen vermeld hun m.i. niet voldoende gemotiveerde agressieve houding tegen de representanten van de traditionele organisatieleer. In een van zijn publicaties had

10) „Een studie over een leider in actie”, Muusses 1956. 
Argyris opgemerkt, dat de scientific administration principles van Taylor, Urwick, Follet, Mooney, e.a. de nadruk leggen op de betekenis van organisatie, maar "had little to say (except kind words) about the individual". Ten aanzien hiervan had ik geschreven: „Wat zijn critiek betreft op Taylor, Urwick c.s. teken ik hierbij aan, dat Argyris voorbij ziet, dat het gebied van de human relations niet het object van studie was en, door hun anders geaarde opleiding en vorming, ook niet kon zijn van de door hem genoemde organisatiedeskundigen. Wordt dit in het oog gehouden, dan lijkt het mij reeds een grote verdienste van de door Argyris genoemden, dat zij zo herhaaldelijk op de betekenis en noodzaak van de studie van de mens en de nienselijke verhoudingen in de bedrijfshuishouding hebben gewezen."

Argyris had mijn geschrift door een van zijn Hollandse studenten laten vertalen en begon vrijwel direct over de even geciteerde critiek. De laatste tijd had hij opnieuw en uitvoeriger de opvattingen en beginselen van pioniers op het gebied van de zgn. wetenschappelijke bedrijfsleiding bestudeerd en geëvalueerd. Een deel van de problematiek door hem in ,Executive Leadership" en andere publicaties aan de orde gesteld - onvolledig aan te duiden als het conflict tussen systeem en individu en de gevolgen daarvan voor productiviteit, efficiency en menselijke waardigheid - was hij voornemens binnenkort in een nieuw boek preciezer en gedocumenteerder te beschrijven. En in dat boek, zo begreep ik hem, zou een andere, zij het nog wel zeer critische, waardering over de traditionele organisatieleer tot uitdrukking komen. Het betreffende boek "Personality and Organization" (284 blz.) is inmiddels verschenen, maar ik heb nog geen gelegenheid kunnen vinden het voldoende te bestuderen.

$\mathrm{Bij}$ een fragmentarisch doorlezen trof mij de overvloedige vermelding van naoorlogse, vooral sociaal-psychologische research over bedrijfsproblemen (waardoor een kritisch lezen extra veel tijd vraagt). Mijn aanvankelijke indruk is, dat hij thans de economische organisatieleer inderdaad iets anders waardeert. Urwick, die er aanvankelijk niet zo goed afkwam (zie boven) heet nu de schrijver van een ,illuminating book" over "The Elements of administration".

Wat is, zo vroeg ik, thans naar uw mening het meest brandende bedrijfsprobleem in de Verenigde Staten? Het prompte antwoord was: dat arbeiders en employé's in de bedrijven door het systeem van leidinggeven en organisatie hun individualiteit verliezen, dat ze te "permissive" worden (permissive is letterlijk veroorlovend, d.w.z. te veel met zich laten doen; ook wordt in dit verband wel submissive $=$ onderdanig of onderworpen gebruikt).

Misschien geeft de omslag van zijn laatste boek het in a nutshell in zijn eigen woorden weer:

,The focal theme of the book is that formal administrative structure tends to make the employee feel dependent, submissive, and passive; that strong, dynamic leadership, management controls, and "human relations" programs tend to reinforce the basic causes of employee-antagonism rather than to decrease them."

Wat dit laatste betreft: er begint in de Verenigde Staten en ook elders de laatste jaren een toenemende zeer critische instelling tegen bepaalde aspecten van human relations en management development programs te ontstaan. Die critiek houdt o.a. in, dat de deelnemers aan deze cursussen naar eigen oordeel en naar dat van hun superieuren wel hun inzicht en kennis in tal van belangrijke bedrijfsproblemen aanmerkelijk verbeteren, maar niet, naar uit onderzoek is gebleken, hun wijze van leidinggeven aan ondergeschikten.

$\mathrm{m} \mathrm{a} \mathrm{b} \quad \mathrm{blz}, 386$ 
Het gesprek met Argyris kon niet lang duren, want hoewel het een Amerikaanse feestdag was waarop alle zaken gesloten waren, moest hij zich naar twee firmanten spoeden, die - succesvol in zaken - toch elkaar moeilijk konden verdragen en hem in verband daarmede in consult hadden genomen!

$\S 6$ Ongeveer ten tijde van mijn bespreking met Argyris viel het mij op, hoe een werk van William $H$. Whyte Jr., ,, The Organization Man", waarop Prof. Dale mij reeds vroeger, zij het niet zonder voorbehoud, had geattendeerd, hoog op de lijst der meest gevraagde boeken noteerde. Aangezien dit boek sinds kort ook als pocketbook $(\$ 1.45)$ is verschenen, het overeenkomst lijkt te vertonen met Argyris' stellingen en sommigen het voorts blijken te kopen in de verwachting er een verhandeling over organisatieproblematiek in te vinden, deel ik omtrent de inhoud het volgende mede.

Whyte is assistent-editor van het tijdschrift ".Fortune", hetgeen waarschijnlijk de betrekkelijk vlot leesbare vorm verklaart. $Z_{\text {ijn }}$ boek gaat niet over bedrijfsorganisatie of de mens in de organisatie, maar over het verschijnsel dat naar zijn mening de Amerikaanse mens meer en meer bezig is zijn individualiteit prijs te geven en zijn heil te zoeken in het deel uit maken van, resp. in de onderschikking aan groepen en groepsleven.

Het probleem dat Whyte in zijn boek aan de orde stelt lijkt een variant op het oude vraagstuk van de tegenstelling tussen individualisme en vormen van collectivisme. Hoewel Whyte zich richt op de maatschappij in het algemeen - op de ..new American way of life" - leqt hij bij zijn beschouwingen sterk het accent op het sociale leven in de bedrijven. Sociologen als Max Weber 11) hebben reeds lang qeleden veel aandacht aan ten dele verqeliikhare verschijnselen in de grote overheids- en particuliere bureaucratieën geschonken, maar als ik me niet vergis kent Whyte aan de zgn. sociale orqanisatie in de bedrijven een arotere alaemene betekenis toe dan zij deden. De titels van de zeven hoofdstukken geven daaromtrent enige aanwijzing: 1. The ideologie of organization man. II. The training of orqanization man, III. The neuroses of organization man. IV. The testing of organization man, $\mathrm{V}$. The organization scientist, VI. The organization man in fiction, VII. The new suburbia: organization man at home.

Whyte's zora is vooral dat de geincrimeerde tendenz een conformistisch, niet meer striidbaar mensentype creëert en ernstiqe schade doet aan het menseliike scheppingsvermogen c.q. aan de produktiviteit en efficiency. omdat de creativiteit van het individu in het algemeen ver uitgaat boven die van een groep. Whyte's stelling nader gepreciseerd is ongeveer, dat le de maatschappij (of stromingen daarin) groepswerk is gaan zien als een bron van creativiteit, $2 e$ de mens zich is gaan suggereren, dat zijn essentiële behoeften alleen in qroepsvormen bevrediad kunnen worden, en $3 e$ dat vooral de wetenschap - in het bijzonder de human relations richting van Elton Mayo c.s. - daarvoor de. ondeugdeliike, bouwstoffen heeft aangedragen en nog steeds aandraagt. Mayo. zegt hij ergens, is meer evangelist dan wetenschapsman.

Gelijk opgemerkt gaat Whvte's boek niet direct over organisatieproblemen in de traditionele zin, maar voor een belangrijk deel over de geestelijke achterqronden of uitgangspunten van het bedrijfsbeleid. Een aangelegenheid, die overigens de organisatieleer wel raakt, omdat deze achtergronden in menig opzicht ook richtinggevend zijn voor de toegepaste organisatie en het personeelsbeleid in een bedrijf. Zo kan de door Whyte gesignaleerde

11) Het verband met Max Weber blijkt o.a. uit het feit, dat Whyte het vraagstuk ook wel als een overgang van protestantse naar sociale ethiek formuleert. Hij noemt trouwens Max Weber (en Durkheim) explicite. 
tendenz zich o.a. uiten en uit deze zich in een onjuiste strukturering van groepswerk (teams, commissies, comité's e.d.) in het geheel van de organisatiebouw en een onjuiste formulering van hun functie en taak.

Een goede en verantwoorde beoordeling van Whyte's boek - taak o.a. voor socioloog, sociaal-psycholoog, political scientist en bedrijfseconoom vraagt veel meer tijd dan één keer lezen en herlezen van sommige passages. Mijn doel met bovenstaande opmerkingen is dan ook, zoals ik reeds schreef, van veel beperkter aard. Van de lezing van het boek heb ik als eindindruk behouden, dat Whyte in zijn strijd tegen de ,,antithese" te veel terug wil naar de "these" en te weinig het oog gericht houdt op de mogelijkheden van de synthese.

Tot slot merk ik in dit verband nog op dat de schrijver niet verward moet worden met zijn naamgenoot, n.l. met de in Amerikaanse kringen gezaghebbende figuur van Prof. William Foote Whyte, Professor of Industrial Relations aan The New York State School of Industrial and Labor Relations en aan de Cornell University, en tevens director van het Social Science Research Center. ${ }^{12}$ )

§ 7 Waar mijn bezoek de studie van automatiseringsvraagstukken betrof, heb ik uiteraard tal van gesprekken met administrateurs en administratieve organisatiedeskundigen gevoerd. 1) Allen wezen er op dat de diepgaande invloed van de elektronificatie zowel op de administratieve als op de overige organisatie niet moet worden onderschat. De controller van Sylvania Electric Products Inc., welke onderneming, op basis van een Univac. een grootscheeps data processing systeem aan het ontwikkelen is, merkte op dat hun ,program required the development of an entirely new organization". Het organisatieschema van het data processing center van dit bedrijf gaat ter illustratie hiernevens.

Wat men in organisatieschema's meestal niet duidelijk naar voren ziet treden is het feit, dat sommige bedrijven twee groepen van organisatiedeskundigen in hun topstruktuur hebben opgenomen. De ene groep is belast met het methodenonderzoek, betrekking hebbend op de in het bedrijf zijnde administratiecomputer(s), terwijl de andere zich met hetzelfde onderzoek bezig houdt, maar dan gericht op elektronische administratieapparatuur van andere fabrikanten (fictieve toepassingen dus). De reden daarvan is, dat deze bedrijven, die alle over hun machines tevreden bleken, zich toch niet onvoorwaardelijk voor de toekomst aan hun leverancier wensen te binden en open willen blijven voor de voordelen en mogelijkheden van andere apparatuur. $Z_{\text {ij }}$ achten daartoe te meer reden anwezig nu elektronische administratiemachines zulke enorme huursommen en/of investeringen eisen en er op het betreffende gebied een vrij uitgebreide concurrentie met vaak belangrijke verschillende systemen, die niet zo maar aan de buitenkant beoordeeld kunnen worden, is ontstaan of bezig is te ontstaan.

12) W. Foote Whyte behoort evenals o.a. Morris S. Viteles tot diegenen, die niet meedoen aan de overaccentuering van human relations in hun betekenis voor produktiviteit en efficiency.

Om een voorbeeld te noemen. De bezwaren, die wel van de "human relations" kant worden ingebracht tegen prestatieloonsystemen e.d. en die soms resulteren in aanbevelingen tot afschaffing van zulke systemen, worden door W. Foote Whyte critisch beoordeeld.

,.The issue then is not: economic incentives or human relations. The problem is to fit economic incentives and human relations effectively together, to integrate them."

..If financial incentives are to be used in the future with full effectiveness, management decisions must be based upon research and experimentation designed to devise an integrated program of incentives and human relations."

Zie Harvard Business Review, maart-april 1952; zie van W. F. Whyte ook "Money and Motivation". New York 1955, en van Morris S. Viteles "Motivation and Morale in Industry", New York 1953.

m a b blz. 388 


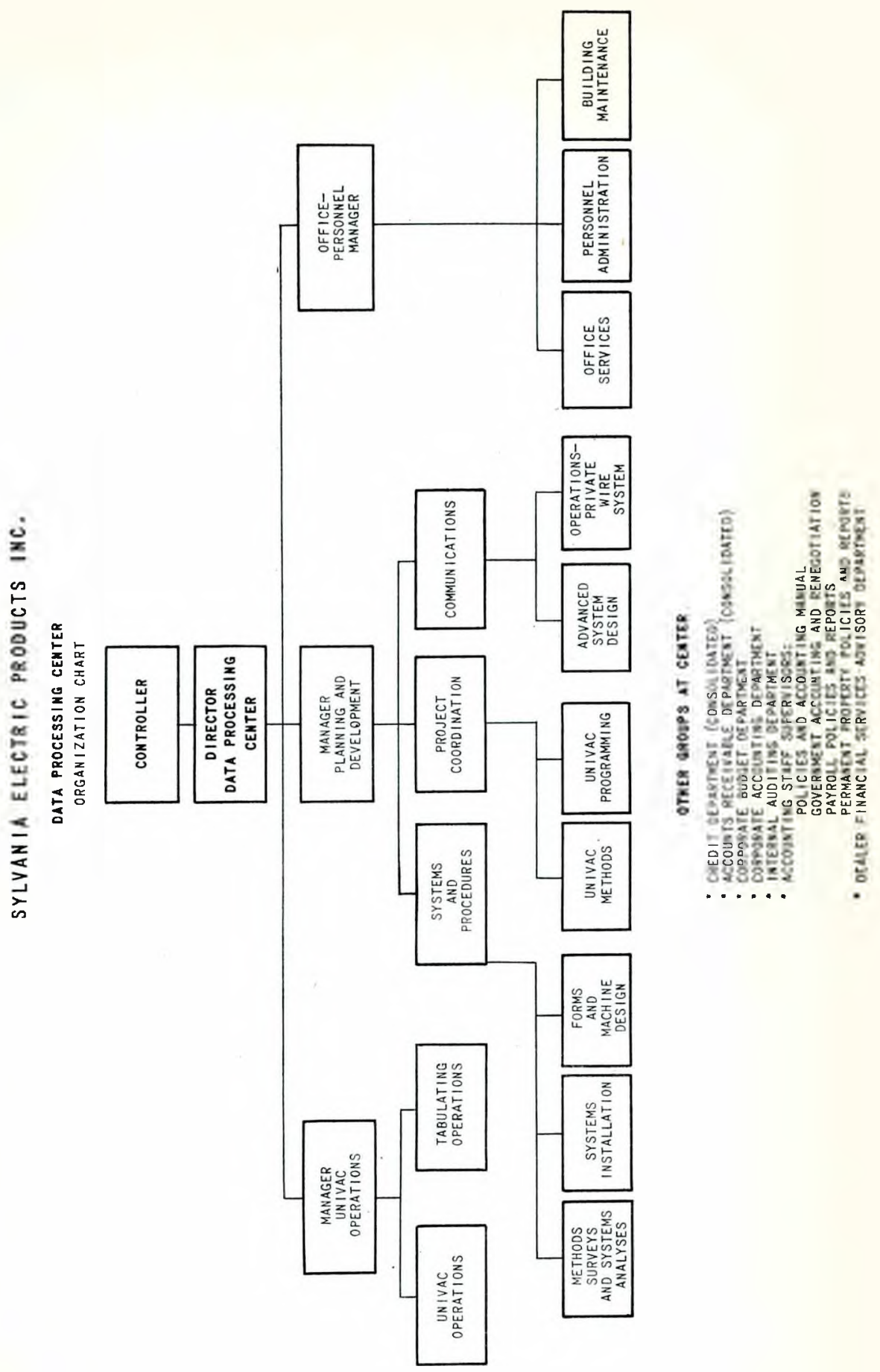

m a b blz. 389 
In een der bezochte bedrijven waren de beide activiteiten nadrukkelijk in de organisatiestruktuur opgenomen, resp. „methods research" en ,new system development" geheten. De leider van de laatste afdeling vertelde mij, dat hij meer dan de helft van het jaar op reis was in de Verenigde Staten en Canada om andere bedrijven, waar grote elektronische administratiemachines ingevoerd zijn, te bezoeken. $\mathrm{Er}$ is in deze bedrijven weliswaar een „,bezoekprobleem" ontstaan, maar men ontvangt overal gaarne deskundige bezoekers, die ook zelf wat te bieden hebben.

Bij de Minnesota Mining and Manufacturing Company te St. Paul (Minn.) zag ik niet alleen een intensief gebruik van c.q. geëxperimenteer met een IBM 705, maar ook voor het eerst een systeem van lopende banden in de administratie voor de ,oude" ponskaartenapparatuur. Aan de betreffende reisnotities ontleen $\mathrm{ik}$ daaromtrent het volgende: „Een binnenkomende order passeert via een systeem van lopende banden, allerlei afdelingen, waar de bijbehorende voorgeponste kaarten worden bijgezocht. Zo wordt er bijgezocht een kaart voor het artikel, zowel in codenummer als geponst in volle tekst, een kaart voor de hoeveelheid, voor de prijs, voor de verkoper, voor de termijn - en rabatclausules, e.d. Bij een laatste afdeling worden tenslotte de niet op voorgeponste kaarten vastliggende gegevens, als die betreffende ,,shipping" e.d., geponst. De totale hoeveelheid kaarten gaat vervolgens in een 604-machine. Deze berekent en ponst dan uitgaande van eenheidsprijs, hoeveelheid, rabatgegevens (evt. variërend per verkoper, artikel, hoeveelheid, betalingstermijn) het rabat en hierna de bruto- en nettoprijs. Tenslotte worden alle benodigde gegevens met een 104-tabulator in de vorm van een factuur uitgetypt op kettingformulieren.

Van de geponste kaarten heeft men voor iedere mogelijke prijs, hoeveelheid e.d. een stapel kaarten gereed staan. Op gezette tijden worden deze aangevuld. Het interessante bij de gehele opzet is, dat alle eenmaal gebruikte kaarten worden weggegooid! Het zou natuurlijk mogelijk zijn deze door sortering en interpolatie weer in de oorspronkelijke vakken te krijgen. Onder Amerikaanse verhoudingen van materiaalkosten en arbeid schijnt het beschreven systeem echter voordeliger."

Met bovenstaande fragmentarische weergave van de inhoud van enige gesprekken moge ik volstaan. Amerika is een land waar op het gebied van leiding, organisatie en arbeidsverhoudingen veel ondernomen wordt en veel in beweging is. Zelfs en passant kan men er heel wat belangwekkends waarnemen, maar een critisch oog en oor zijn daarbij wel zeer gewenst. 